PROBLEMS

OF EDUCATION

IN THE $21^{\text {st }}$ CENTURY

Vol. 78, No. 6A, 2020

1096

\title{
FOSTERING AUTONOMOUS LANGUAGE LEARNERS AT A JAPANESE UNIVERSITY
}

\author{
Mayumi Kanazawa \\ Kibi International University, Japan \\ E-mail: mymkanaz@kiui.ac.jp
}

\begin{abstract}
Autonomous learning is one of the most important factors in the field of language learning. Leaning a language demands a considerable amount of time and learners have to work inside and outside the classroom to develop their language skills. The present study explored ways of promoting autonomous learning skills in mixed-level of students of English at a Japanese university. The course syllabus, which employed various methods was developed in order to increase students' autonomous learning skills and incorporate a self-study period during the semester. The students set their own goals, then planned, developed and followed strategies to achieve them. Learners also kept a weekly learning-log, culminating in a presentation and a written report about what they had done to achieve their goals, including selfevaluation. The results showed that the students recognized some improvements in their English learning skills, motivation and learning habits, including an increase in learning hours. In addition, the students gained confidence in their English learning. Further practical improvements are suggested for supporting students to become autonomous language learners.
\end{abstract}

Keywords: autonomous learners, language learning, learner autonomy, learner independence, selfstudy

\section{Introduction}

The direction of English education at universities promoted by the Ministry of Education, Culture, Sports, Science and Technology in Japan states that it is extremely important to improve ability in English, which is an international common language, as globalization progresses (2014). In the current era of rapid globalization, students need to spend considerable time learning the language, including studying outside the classroom. However, many university students seem to lack study habits and is assumed that they do not sufficiently acquire abilities to 'prepare and review for classes' or 'do assignments'. The Institute for Labor Policy (2001) compared weekly study hours (outside classroom) of university students in 9 European countries (Norway, Italy, Austria, Spain, the U.K., the Netherlands, Germany, Finland, France) and Japan. The average of the nine European countries' weekly study hours was 15.5 hours. The longest duration was 23.6 hours and the shortest was 13.3 hours. Meanwhile, Japanese weekly study hours amounted to 7.1 hours. It revealed that Japanese university students do not spend enough time studying. Also, the National Institute for Educational Policy Research (2016) showed that Japanese university students' weekly average study time (outside classroom) was 7.9 hours.

English has played an important role in Asian countries for decades. It has become a common language in the fields of trade, commerce, diplomacy, tourism, mass media, and academic pursuit across the world. For Asian countries, English is now an indispensable resource which they seek for themselves and their younger generations for successful participation in the global economy. Japan is no exception. The Japanese government has set proposed changes in English education, such as starting English class at elementary schools and set the new targets to acquire the four skills in high schools. However, Japanese English proficiency level is low 
among Asian countries. According to a survey by EF English Proficiency Index (2019), which reports the rank of English proficiency every year, Japan was ranked $53^{\text {rd }}$ out of 100 countries and regions in 2019. Among East Asian countries, China, Taiwan and South Korea, rank higher than Japan. Japan has continued to fall in rank since the survey started in 2011. There are various possible explanations. Short study hours and low motivation in learning English seem to be contributing factors. .However, given the limited contact time Japanese students have in the university, a major factor is lack of autonomous learning. Traditionally, Japanese students are considered to be passive and dependent on teachers (Dore \& Seko, 1989). Teachercentered English classrooms have been common in Japan, where teaching is largely one-way from a teacher to students. Students expect the teacher to tell them what to do and how to do it. This suggests that students depend on their teachers and are, not actively responsible for their learning. It could therefore be said that opportunities for students taking initiatives in the classroom have not been provided, which has resulted in their current behavior. Also, from the author's observation, students do not actively seek ways to acquire the language despite being surrounded by rich resources and a variety of means to learn English on their own. Even though Language Learning Center or CALL (Computer Assisted Language Learning) systems are in place, only the most motivated learners actually take up the offer and make use of them. The author believes that language competence comes not only from doing assignments given by the teachers but also from students working independently on their own needs. Nevertheless, it is challenging for students to find the way to carry this out. In order to help students to develop independent language learning habits outside the classroom, a classroom-based self-directed learning program should be incorporated to transfer to students the responsibility for language learning processes, such as setting goals, selecting materials and learning strategies, and evaluating learning progress. Students need to be given the skills to be able to seek out materials and resources to enable them to improve their recognition of what is relevant and what is not. Also, they need some support to learn how to utilize these skills. If this lack of experience in autonomous learning continues, their prospects look bleak. Therefore, the decision was taken to incorporate autonomous learning in a taught syllabus which functions as a springboard for students' self-directed study.

\section{Literature Review}

There has been remarkable growth of interest in autonomy in language teaching and learning (Benson, 2006). What is learner autonomy? Holec (1981, p.3) defined the term 'learner autonomy' as "the ability to take charge of one's own learning", which has been widely cited in the field. There are different perspectives of 'autonomy'. Dickinson (1987) defined it as "the situation in which the learner is totally responsible for all of the decisions concerned with his learning and the implementation of those decisions." Autonomy is not an individual ability but a 'situation', and the 'situation' in which the learner is completely independent of the organizations such as schools, teachers and prepared materials is called autonomy. Benson and Voller (1997) noted that there are five categories of learner autonomy: (1) situations in which learners study entirely on their own; (2) a set of skills which can be learned and applied in self-directed learning; (3) an inborn capacity which is suppressed by institutional education; (4) the exercise of learners' responsibility for their own learning; and (5) the right of learners to determine the direction of their own learning. Learner autonomy refers to "the capacity to take control over one's own learning," and autonomous learning refers to "learning in which learners demonstrate a capacity to control their learning." Benson (2011, pp. 123-124). Holec (1985) also stated that learner training should prepare students to direct their own learning so that they may gradually move from dependence on a teacher to a degree of independence or autonomy. Lee (1998) concurred, commenting that a certain degree of learner training is

\author{
PROBLEMS \\ OF EDUCATION \\ IN THE $21^{\text {st }}$ CENTURY \\ Vol. 78 , No. $6 \mathrm{~A}, 2020$ \\ 1097
}


Mayumi KANAZAWA. Fostering autonomous language learners at a Japanese university

PROBLEMS

OF EDUCATION

IN THE $21^{\text {st }}$ CENTURY Vol. 78 , No. 6A, 2020

1098

necessary before students can truly become responsible learners. Meanwhile, Sinclair (1999, p. 310) defined autonomy as "being self-directed," but suggested that learners' capacity to make informed decisions needs to be developed by teachers' support. Thus, self-directed learning has the potential to promote independence in learners so that they can continue their learning. In autonomous learning, learners are expected to have the responsibilities of setting goals, making plans to achieve their goals, implementing learning strategies, monitoring their learning process, and evaluating their learning (Cotterall, 2000). According to Smith (2007), learner autonomy is activated when "learners have the power and right to learn for themselves" (p. 2). Thus, autonomous learners' willingness and capacity to control their own learning are essential.

What can be done to foster learners' autonomy? Fostering learner autonomy may be defined in simple terms as helping learners to become more independent by training them to use language learning strategies effectively in their language learning process. Cotterall (2000) advocated that principles of learner autonomy should be integrated into the classroombased courses and, to this end, offered five principles for language courses. These principles are designed to foster learner autonomy and support the transfer of responsibility for decision making from teacher to learner (Cotterall, 2000):

1. The course reflects learner's goals in its language, tasks, and strategies.

2. Course tasks are explicitly linked to a simplified model of the language process.

3. Course tasks either replicate real-world communicative tasks or provide rehearsal for such tasks.

4. The course incorporates discussion and practice with strategies known to facilitate task performance.

5. The course promotes reflection on learning.

Cotterall concluded that courses adopting these five principles helped learners understand and manage their learning in a way that contributed to their performance in specific language tasks. Also, learner motivation was enhanced. It suggests that the program incorporated in the classroom-based activities is effective in fostering autonomous learning. However, there are few reports of such integrated courses. Iimuro and Berger (2010) developed 'Self-Study' as an assignment, with the aim of integrating autonomous learning aspects into the course. They reported that the guided study implemented in the curriculum was successful in motivating students to study consistently to achieve the language skills and study habits. However, they also mentioned there was room for improvement in terms of providing various examples of study methods and materials. Still, it is apparent that there are benefits to incorporating a systematizing project as a course requirement. Therefore, the sufficient time for providing possible materials, study methods, and demonstration of practice opportunities should be provided before learners carry out their own 'self-study'. Previous studies have suggested potential effects of autonomous learning programs; however, the number of empirical studies on this topic is limited in Japan. As put forward by Cotterall (2000), incorporating principles of learner autonomy is considered vital. With this in mind, the classroom-based course was designed to integrate principles with practice. In doing so, the course would function as a means of fostering autonomous learners who would keep learning for their own language development. 


\section{Research Questions}

This study explored whether autonomous learning was promoted by incorporating 'selfstudy' into a classroom.

The research questions were as follows:

1. What are the effective teaching strategies for promoting autonomous learning?

2. What did students change after autonomous learning promotion in terms of learning time, learning strategies, motivation, and learning behavior?

\section{Research Methodology}

\section{General Background}

The study was conducted in 2019. In this classroom-based course, various kinds of activities were provided by the teacher in an attempt to train students in language learning strategies. The activities in the strategy training process included materials and exercises focusing on teaching reading, listening, speaking, writing, and vocabulary building strategies. Also, two kinds of 'Logs' were used for promoting engagement with English outside the classroom and reflection on learning. This study used mixed methods research design, combining quantitative and qualitative methodological approaches.

\section{Sample}

The students who enrolled in the 'Learning Skills' course were in their second year at Kibi International University. The number of students in this course was 19 (male 7, female 12). All of the students were going to study abroad from the next semester in fulfillment of the graduation requirement. They were required to acquire ample language skills to be successful in studying abroad. Their TOEIC IP scores ranged from 320 to 745 with an average score of 468 at that time. The students whose English proficiency was relatively low had no experience of using language-learning strategies. At the beginning, students were informed the data would be used for research. The students were advised of the research project and were invited to ask any questions. Students then consented to the anonymous data being included in the research and in the resulting paper.

\section{Instruments and Procedures}

This study utilized the following three instruments. These instruments were designed to prompt students to recognize their actions and make decisions about what to do to reach their own goals. In addition, reflection on their learning in form of a presentation and report aimed to help students increase their ability to be more independent.

1. Weekly Log - to record any increase in learning hours outside the classroom.

2. Learning $\log$ (self-study in class) - to identify the materials and method suited to learners' needs.

3. Presentation and report - to demonstrate any findings related to students' motivation and their learning habits. 
Mayumi KANAZAWA. Fostering autonomous language learners at a Japanese university

PROBLEMS

OF EDUCATION

IN THE $21^{\text {st }}$ CENTURY

Vol. 78 , No. 6A, 2020

The study was implemented in the 'Learning Skills' course in the spring semester 2019. In the first eight classes of the semester, various English learning strategies were introduced to meet the students' needs in improving the four English skills. These included different resources, such as news articles, English learning sites on the Internet and YouTube videos. After each class, students were required to reflect and write notes on what they had learnt during the session. In the subsequent class, the idea of autonomous learning and the rationale for 'Self-study' was incorporated in the course. Using a study plan sheet, the students set their own goals and made learning plans including the materials to use for the next four weeks. During the four-week period, half of each lesson (45 minutes) was allocated to self-study. The students were expected to work towards their own goals and plans and be responsible for their own study using the materials they had prepared. The students could consult the teacher if they needed any help finding materials to use. At the end of each class, the students wrote what they had actually done in the session and their comments in the Learning Log. These reflective notes were submitted and returned with some comments from the teacher in the following week. Also, the students were required to set the goal of study hours for the next week and keep a Weekly Log in which they recorded starting and finishing times, total learning hours and the activities. The teacher collected the Logs and provided feedback on the students' work. In the last two weeks of the semester, the students made presentations with PowerPoint, reporting on the month's work both inside and outside the classroom. In their presentation and written reports, students were required to include the following: (1) goals; (2) materials and the methods to exploit; (3) achieved or not (why, why not) and (4) next step towards learning English.

To sum up, these activities are regarded as a reflection on learning, as set out in Cotterall's fifth principle (Cotterall, 2000). They gave students opportunities to be aware of their learning activities and behavior.

\section{Data Analysis}

Based on the research questions, the data were analyzed using a range of instruments. The Weekly Log and the Learning Log were submitted in class. The weekly learning hours were calculated by Excel to acknowledge the amount of time for learning English. In order to identify the learning tools and learning strategies, a 5-point Likert scale was used and summarized in the results. Key words and sentences related to motivation and learning attitudes in the students' reports were collected for examination.

\section{Research Results}

\section{Learning Hours Outside of Classroom Increased}

Students' weekly learning hours were recorded over four weeks, as Figure 1 indicates. This data was collected from the Weekly Log submitted by students. The weekly average of learning hours among 19 students was 13.07 hours. In their first year questionnaire, the students answered that the average time they spent on learning was 7.5 hours. It is obvious that they devoted more time to learning English in the second year than in the first. 
Figure 1

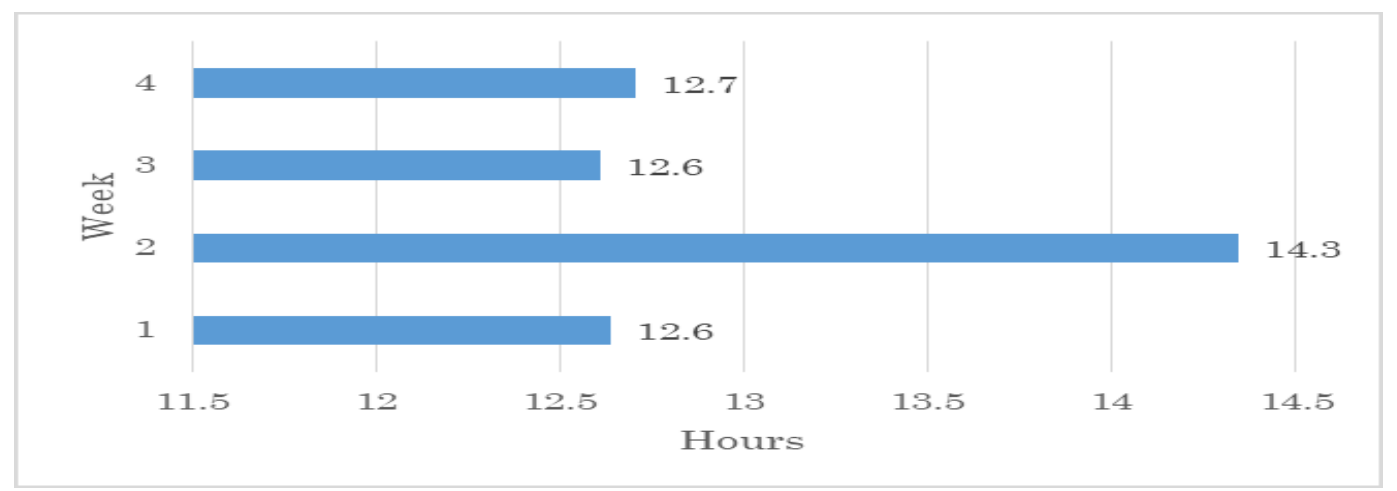

Students' total individual hours are calculated for the four-week period and shown in Figure 2. According to the Logs, 13 out of 19 students spent over 40 hours learning outside the classroom, which was the initial minimum goal for the quantity of learning hours. One of the students achieved over 100 hours. The average total number of learning hours of the 19 students was 46.7 hours. The number of hours in the second week was considerably higher compared to that for the other weeks, which suggests that students were more motivated after the first week, due to figuring out how to shape their learning.

\section{Figure 2}

Individual Total Learning Hours (4 weeks)

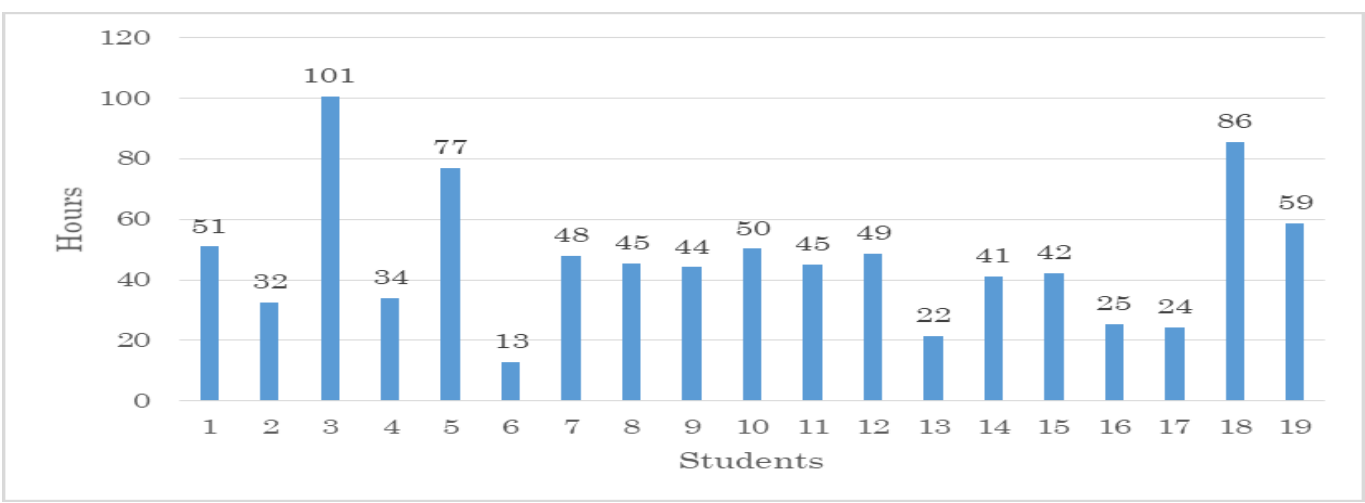

Students'Learning Strategies and Own Evaluation

In the 'Learning Log' during the 'self-study' weeks, the participants answered questions about their own English learning activities during the class. The results of 5-point Likert scale are summarized in Table 1 (5: Entirely, 1: Not at all). As Table 1 shows, none of the student chose 3 (Somewhat) to 1 (Not at all). This indicates that all of the students were positive about what they did. They thought that the materials they selected were useful and met their needs. In addition, they enjoyed the way they used the materials and had desire to continue that. 
Mayumi KANAZAWA. Fostering autonomous language learners at a Japanese university

PROBLEMS

OF EDUCATION

IN THE $21^{\text {st }}$ CENTURY

Vol. 78, No. 6A, 2020

1102

Table 1

Self-evaluation on Own English Learning in the Classes (\%)

\begin{tabular}{lccccc}
\hline & 5 & 4 & 3 & 2 & 1 \\
& (Entirely) & (Largely) & (Somewhat) & (Not really) & (Not at all) \\
\hline I enjoyed it & 53 & 47 & 0 & 0 & 0 \\
\hline I want to continue & 74 & 26 & 0 & 0 & 0 \\
\hline It is useful & 74 & 26 & 0 & 0 & 0 \\
\hline It matches me & 63 & 27 & 0 & 0 & 0 \\
\hline
\end{tabular}

In the students' presentation and report, a variety of learning tools and learning strategies were identified. The most used resources as learning tools were YouTube and the English learning site, 'Quizlet'. Regarding YouTube, students preferred songs, TED talks, animations and movies as language learning instruments, mainly focusing on listening improvement. They also adjusted the speed of speech to strengthen listening skills. Quizlet was widely used among students because it was recommended by teachers during the semester to build up their vocabulary. It was possible to learn and increase vocabulary in a variety of ways, including making their own flash cards. Students who wanted to improve their speaking skills used two different methods to practice speaking. One was to have time to talk to native English teachers and exchange students in English as much as possible; the other method was talking by themselves for five minutes and recording it. Users of both methods mentioned that they enjoyed the activities and recognized improvement in their speaking skills. For writing practice, writing a journal or a diary was a common approach, as was writing a summary of an article. In their presentation and written reports, students described in detail the methods they utilized.

\section{Evaluating Teaching Strategies}

In this study, several teaching strategies were implemented. Utilizing two kinds of 'Logs' was one of the effective strategies to promote students to drive learning behavior and develop language learning awareness. Keeping a record of setting learning target times and daily learning in the 'Weekly Log' made students realize their involvement in the program. In particular, setting a learning target time played an important role in increasing learning hours outside the classroom. The 'Learning Log', which was used in class, helped students examine whether the plan was actually implemented. Moreover, it made them recognize whether the plan, including materials and strategies, suited their own proficiency level and preference, and examine whether it met their expectations. Some students reported that they modified subsequent plans and changed learning activities to meet their targets. They claimed that it was a great achievement for them to reach their goals. Another effective teaching strategy was dividing a class hour in half in order to introduce learning strategies with practice time and implement students' own 'self-study' time in a supported setting. Following the strategy practice, students were able to use the newly learned strategies in their own learning plan, which in turn led to greater awareness of learning strategies. These teaching strategies helped students to notice and monitor their own learning, and subsequently, reflect on their study patterns and accomplishments. 
In the student presentations and reports, the majority of comments were positive. Among these positive comments, three trends emerged; recognition of improvement in English skills, discovery of new learning strategies, and increase in motivation. Students who commented on their improvement in their English skills reported the following (the comments were written in Japanese by the students and translated into English):

- My listening skill was improved by listening at 1.5 times speed.

- I realized my English had improved.

- I was able to talk about Japanese culture after a lot of practice

- I had both better reading and writing skills

The majority of the students commented that they engaged with a greater variety of learning methods and learning strategies by trying out different resources and activities, which they had never attempted before.

- I was able to find suitable learning strategies to me. It was a big success.

- I did something new I have never tried such as speed reading and describing photos.

- It was a good opportunity for me to learn various learning methods and learning strategies.

Comments below are associated with motivation.

- I became more positive about learning English.

- Motivation to study was increased.

- I noticed the consistency of learning is very important for improving English.

- $\quad$ Setting goals and recognizing successful learning outcomes motivated me.

- I want to try more different learning strategies.

- I was not good at planning and keeping to it, but I enjoyed it and I want to set new goals.

- I want to make more efforts to improve listening skills.

From these comments, it is noticeable there were many observations by students regarding motivation and habits. One participant wrote in her report, "I watched a short video clip at 1.5 times speed for listening practice. In the first week, I could not understand it at all, but by the third week, I was able to understand almost everything. I was very happy. I haven't enjoyed watching a video clip in English like this before. I learned the importance of learning continuously." This response demonstrates the effect of continuation. There were no negative comments mentioned about the program or what they were supposed to do, such as "I can't continue", or "Too much workload". However, there still seemed to be a sign which indicated the students' demotivation in the Learning Log. For instance, 3 out of 19 students did not submit the Log for two weeks and another 2 out of 19 failed to submit for one week. They might have simply forgotten to keep the records; alternatively, they might have been unable to submit because they had not done anything to write about during those weeks. To discover and help overcome the potential obstacles, teachers should consider setting individual counselling time or sharing information among peers. In addition, an anonymous feedback survey would be helpful, as this could reveal the students' real intentions and their honest views of the program. 
PROBLEMS

OF EDUCATION

IN THE $21^{\text {st }}$ CENTURY Vol. 78 , No. $6 \mathrm{~A}, 2020$

1104

\section{Discussion}

Setting goals before implementing the program was essential as this process can improve students' learning and motivation (Zimmerman, 1990). However, setting goals was a difficult task for the students. They had to complete the study plan before engaging in the 'self-study' period. Their initial goals were not specific at all. They thought their hopes were their goals to reach, such as being able to speak English fluently or understand native English speakers' English perfectly. Therefore, it took time for them to decide the goals and make plans. There should have been some materials to make it easier for them. However, setting goals for learning hours each week made the participants strive to achieve the hours set, so that learning hours considerably increased. The result indicates that it is beneficial for students to include setting a goal for learning hours in the Learning Log. The students who spent significantly more time outside the class defined clear goals and they were well prepared to take control of their own learning.

Next, the result showed that the students found the suitable learning strategies for themselves to reach their goals. Students' high degree of satisfaction with self-evaluation for their own learning activities revealed that independent selection of resources and materials was crucial for raising learner autonomy. The first eight sessions introduced and demonstrated learning resources and materials. Also, students exploited and practiced both cognitive learning strategies and metacognitive learning strategies so that they could carry out their own learning smoothly. After the four-week 'self-study' period, a variety of work was produced by the students. Some were activities done in the first eight classes; others were from the students' original ideas including writing a 100 -word diary entry every day, making an original vocabulary book and recording their own speaking. Students preferred films, songs and English learning applications on the mobile phones as leading autonomous language learning instruments. Moreover, there was an unexpected, interesting finding. In the beginning of the 'self-study' period, the students took time to start their own learning even though they had already made their own plans. Some spent time just searching the Internet but doing nothing. It was a little odd to see that most students seemed to be uncomfortable doing their own study. At the beginning of the research, the assumption was that the students would be pleased to be able to do something they had decided with their own choice of materials during the class. They were allowed to do anything they wanted to do. However, since they had been accustomed to a structured learning environment, which means being provided materials and instruction by teachers, they were not sure that what they intended to do was right. They still expected the teacher to take most of the responsibility and make most of the decisions about their learning in the classroom context. This might be a reason why the students cannot behave as autonomous learners. Also, it could indicate that doing different things from others in the same class may have influenced their behavior. It appears to be one of the characteristics of Japanese students.

Finally, some changes were observed in the students' motivation and their learning habits. Two main trends were found from their presentation and the written reports. One was the recognition of improvement in English skills; the other was an increase in motivation. The perception of development in their language skills motivated students towards further learning and greater confidence. Inspection of their Logs showed that 6 out of 19 students wrote them in Japanese in the beginning, but 13 out of 19 students had been writing them in English by the last session. It is obvious that their desire to express their thoughts had developed, which is a sign of confidence in writing in English. Some students were determined to set the new goals for the next plans, such as studying abroad and speaking to exchange students on campus. Furthermore, one of the students reported that he had gained not only a large amount of information from the news, which was used for writing summaries, but also come to develop an interest in various events occurring all over the world. This comment suggests that autonomy 
plays an important role in students' learning. In addition, the majority of the students realized the usefulness of making learning plans on their own and importance of continuous study. The sense of achievement and experience of success are important in motivating the students to continue studying. By providing an opportunity for students to experience their development besides examinations, it is certain that autonomous learning is valuable for their future studies.

\section{Conclusions and Implications}

Incorporating 'self-study' in the course syllabus was successful. It was beneficial for the students to gain experience of utilizing various learning strategies and find suitable ones for them. The students noticed numerous phenomena they had never been aware of before. Thus, this type of autonomous learning syllabus consequently raises students' learning motivation and arouses interests. However, there is some room for further improvement. First, more attentive support for setting specific goals was needed as it was not easy for the students to set specific goals. Second, extra time should have been available to check progress of the plans. This could have taken the form of an individual tutorial with the teacher or sharing information and progress among the students. Unfortunately, time constraints did not allow for these measures; however, it would be beneficial if future research and courses set aside time for support activities. Limitations of this study are the small number of participants and the lack of data related to participants' autonomous language learning before implementing the course. From their reports and presentations, there were no negative comments about the course, or what they had done. However, their true intention was difficult to gauge; for instance, politeness to the teacher might have inhibited frankness and negative response. Also, as the study did not track learning after the course, it was not possible to see students become autonomous learners. Therefore, it is important for teachers to support students in acquiring a study habit and building the mindset of an autonomous learner. Only then can students learn how to study even beyond completion of the course.

Generally speaking, participants in this study had positive attitudes toward learning English. They had not had experience of utilizing learning strategies or knowledge of autonomous learning before they engaged in the program. Through acquiring knowledge and practice, it is possible for students to select materials and methods on their own and learn to take actions by themselves. Autonomous learners are not naturally born. However, with some support and guidance from teachers and with learners' persistent effort, this study clearly indicates we can foster autonomous language learners who are able to use learning strategies effectively and monitor and evaluate their language learning process.

\section{References}

Benson, P. (2011). Teaching and researching autonomy in language learning. Longman.

Benson, P. (2006). Autonomy in language teaching and learning. Language Teaching, 40(1), 21-40.

Benson, P., \& P. Voller. (1997). Autonomy and Independence in Language Learning. Longman.

Ceylan, N. O. (2015). Fostering learner autonomy. Procedia - Social and Behavioral Sciences, 199, 8593. http://creativecommons.org/licenses/by-nc-nd/4.0/

Chen, H. I., \& Pan, H. H. (2015). Leaner autonomy and the use of language learning strategies in a Taiwanese junior high school. Journal of Studies in Education, 5(1), 52-64. http://dx.doi.org/10.5296/jse.v5il.6972

Cotterall, S. (2000). Promoting learner autonomy through the curriculum: Principles for designing Language course. ELT Journal, 54(2), 109-117. http://doi.org/10.1093/elt/54.2.109

Department of University Management and Policy Studies. (2007). The National Survey of Student Engagement. http://ump.p.u-tokyo.ac.jp/crump/

Dickinson, L. (1987). Self-instruction in Language Learning. Cambridge University Press. 
Mayumi KANAZAWA. Fostering autonomous language learners at a Japanese university

PROBLEMS

OF EDUCATION IN THE $21^{\text {st }}$ CENTURY Vol. 78, No. 6A, 2020

1106

Dore, R. P., \& Sako, M. (1989). How the Japanese learn to work. Routledge.

EF English Proficiency Endex. (2019). The worlds' largest ranking of countries and regions by English skills. https://www.ef.com/wwen/epi/

Holec, H. (1981). Autonomy and foreign language learning. Pergamon.

Holec, H. (1985). On autonomy: Some elementary concepts. In P. Riley (Ed.), Discourse and learning (pp. 173-90). Longman.

Iimuro, A., \& Berger, M. (2010). Introducing learner autonomy in a university English course. Ritsumeikan Research Repository. (pp.127-141). http://hdl.handle.net/10367/1897

Institute for Labor Policy. (2001). International comparison of activities during the semester. https://www. mext.go.jp/component/b_menu/shingi/giji/_icsFiles/afieldfile/2011/09/30/1311574_4.pdf

Lee, I. (1998). Supporting greater autonomy in language learning. ELT Journal, 52(4) $)$, 282-290. https://doi.org/10.1093/elt/52.4.282

Little, D. (1997). Language awareness and the autonomous language learner. Language Awareness, $6(2-$ 3), 93-104. http://dx.doi.org/10.1080/09658416.1997.9959920

Little, D. (2009). Language leaner autonomy and the European language portfolio: Two L2 English examples. Language Teaching, 14(1), 77-95. http://dx.doi.org/10.1177/s0261444808005636

Lo, Y. F. (2010). Implementing reflective portfolios for promoting autonomous learning among EFL college students in Taiwan. Language Teaching Research, 14(1), 77-95. http://dx.doi.org/10.1177/1362168809346509

Ministry of Education, Culture, Sports, Science and Technology. (2014). Future measures for improving and enhancing English education. https://www.mext.go.jp/b_menu/shingi/chousa/shotou/102/ houkoku/attach/1352464.htm

Myartawan, I. P. N. W., Latief, M. A., \& Suharmanto. (2013). The correlation between learner autonomy and English proficiency of Indonesian EFL college learners. TEFLIN Journal, 24(1), 63-81.

Najeeb, S. S. R. (2013). Learner autonomy in language learning. Procedia - Social and Behavioral Sciences, 70, 1238 - 1242. http://dx.doi:10.1016/j.sbspro.2013.01.183

National Institute for Educational Policy Research. (2016). Research on the learning situation of university students. https://www.nier.go.jp/05_kenkyu_seika/pdf_digest_h29/gaiyou.pdf

Smith, R. (2007). Leaner autonomy. ELT Journal, 62(4), 395-397. http://dx.doi.org/10.1093/elt/ccn038

Thanasoulas, D. (2000). What is learner autonomy and how can it be fostered? The Internet TESL Journal, 6(11). http://iteslj.org/Articles/Thanasoulas-Autonomy.html

Yabukoshi, T., \& Kato, K. (2017). Facilitating Japanese college students' autonomous learning outside the English classroom. The Language Teacher, 41(5), 3-10. http://doi.org/10.37546/JALTTLT 41.5-1

Zimmerman, B. J. (1990). Self-regulated learning and academic achievement: An overview. Educational Psychologist, 25(1), 3-17. https://www.researchgate.net/publication/243775466_Self-Regulated_ Learning_and_Academic_Achievement_An_Overview

Received: October 28, 2020

Accepted: December 20, 2020

Cite as: Kanazawa, M. (2020). Fostering autonomous language learners at a Japanese university. Problems of Education in the $21^{\text {st }}$ Century, 78(6A), 10961106. https://doi.org/10.33225/pec/20.78.1096

Mayumi Kanazawa

MSc, Lecturer, Kibi International University, Okuda-Nishimachi 5-5, Kita-ku,

Okayama, Japan.

E-mail: mymkanaz@kiui.ac.jp

Website: http://kiui.jp

ORCID: https://orcid.org/0000-0003-2298-0946 